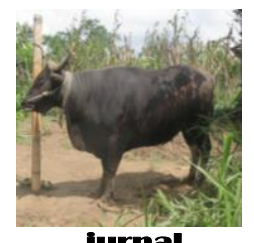

Jurmal FADET UNUD

\title{
PENGARUH PEMBERIAN TEPUNG KULIT KERANG PADA RANSUM KOMERSIAL TERHADAP PERSENTASE KARKAS AYAM ISA BROWN UMUR 105 MINGGU
}

\author{
Adiantara, I P. P., G. A. M. K. Dewi, dan M. Wirapartha \\ PS. Sarjana Peternakan, Fakultas Peternakan, Universitas Udayana, Denpasar, Bali \\ E-mail: pegiadiantara@student.unud.ac.id Hp: +6287848694842
}

\begin{abstract}
ABSTRAK
Penelitian ini bertujuan untuk mengetahui pengaruh pemberian tepung kulit kerang pada ransum komersial terhadap persentase karkas ayam Isa Brown umur 105 minggu. Rancangan yang digunakan dalam penelitian ini adalah rancangan acak lengkap (RAL) dengan empat perlakuan tiap perlakuan menggunakan 5 ulangan dan setiap ulangan menggunakan 3 ekor ayam Isa Brown. Keempat perlakuan tersebut adalah perlakuan A ransum komersial tanpa tepung kulit kerang, $\mathrm{B}$ ransum komersial dan 1\% tepung kulit kerang, $\mathrm{C}$ ransum komersial dan $2 \%$ tepung kulit kerang, D ransum komersial dan 3\% tepung kulit kerang. Variabel yang diamati dalam penelitian ini antara lain bobot potong, bobot karkas, persentase karkas, persentase dada, persentase sayap, persentase paha dan persentase punggung. Hasil penelitian menunjukan bahwa persentase paha pada perlakuan $\mathrm{B}$ dan $\mathrm{D}$ nyata $(\mathrm{P}<0,05)$ lebih tinggi dibandingkan dengan perlakuan $\mathrm{A}$ dan $\mathrm{C}$. Berdasarkan dari hasil penelitian ini dapat disimpulkan bahwa pemberian tepung kulit kerang pada level $1 \%$ dan 3\% pada ransum komersial dapat meningkatkan persentase paha, namun tidak dapat meningkatkan bagian bobot potong, bobot karkas, persentase karkas, persentase dada, persentase sayap dan persentase punggung ayam Isa Brown umur 105 minggu.
\end{abstract}

Kata Kunci : tepung kulit kerang, persentase karkas, ayam isa brown

\section{THE INFLUENCE OF SHELL FISH FLOUR ON COMMERCIAL RATIONS ON THE CARCASS PERCENTAGE OF ISA BROWN CHICKEN AGE 105 WEEKS}

\begin{abstract}
This study aims to determine the effect of shellfish flour meal on commercial rations on the percentage of Isa Brown chicken carcasses aged 105 weeks. The design used in this study was a completely randomized design (CRD) with four treatments per treatment using 5 replications and each test using 3 Isa Brown chickens. The four treatments were A commercial ration without clamshell flour, $\mathrm{B}$ commercial ration and $1 \%$ clamshell flour, $\mathrm{C}$ commercial ration and 2\% clamshell flour, commercial D ration and 3\% clamshell flour. The variables observed in this study included cutting weight, carcass weight, carcass percentage, chest percentage, wing percentage, thigh percentage and back percentage. The results showed
\end{abstract}


that the percentage of thighs in treatments $\mathrm{B}$ and $\mathrm{D}$ was significantly $(\mathrm{P}<0.05)$ higher than that of treatments $\mathrm{A}$ and $\mathrm{C}$. Based on the results of this study it was concluded that the administration of clamshell flour at the level of $1 \%$ and $3 \%$ in commercial rations can increase the percentage of thighs, but can not increase the weight of the cut, carcass weight, carcass percentage, breast percentage, wing percentage and the percentage of chicken back Isa Brown aged 105 weeks.

Keywords: shell fish flour, carcass percentage, isa brown chicken

\section{PENDAHULUAN}

Ayam petelur adalah salah satu ternak yang dapat memenuhi kebutuhan protein hewani, selain telur tentunya daging yang dihasilkan dapat dikonsumsi oleh masyarakat. Hal tersebut digambarkan karena ada masanya yaitu ayam petelur produktif dan sampai puncaknya pelanpelan produksi telurnya menurun. Menurunnya produksi telur dari ayam petelur banyak faktor yang menyebabkan, salah satunya adalah umur produksi. Strain Isa Brown mulai berproduksi umur 18-19 minggu, jumlah telur 351 butir, puncak produksi mencapai 95\%, dan bobot badannya $2,01 \mathrm{~kg}$, bobot telur ayam Isa Brown mulai meningkat saat memasuki umur 21-36 minggu, dan relatif stabil di umur 50 minggu (Isa Brown Commercial Layers, 2009).

Ayam yang mendekati masa afkir produksi telurnya akan terus menurun hingga produksi telur berhenti pada masa yang disebut masa afkir. Umumnya ayam petelur harus sudah diafkir pada umur 80 minggu karena semakin bertambahnya umur ayam kualitas telur yang dihasilkan akan semakin menurun, hal ini diakibatkan kandungan mineral dalam tubuh ayam semakin berkurang (Hargitai et al. 2011). Pakan yang sesuai dengan kuantitas dan kualitasnya akan membuat pertumbuhan ayam menjadi baik. Pertumbuhan secara umum diartikan sebagai proses perubahan yang meliputi pertambahan berat hidup, perubahan bentuk, dan komposisi tubuh ternak. Judge et al. (1989) menyatakan, bahwa selama pertumbuhan proporsi tulang, daging dan lemak akan mengalami perubahan, pertumbuhan tersebut akan mempengaruhi bobot karkas dan potongan komersial karkas, karkas merupakan ternak yang sudah dipotong yang dihilangkan kepala, kaki, bulu dan organ dalam, potongan komersial karkas ayam dibagi menjadi lima bagian yaitu paha atas, paha bawah, sayap, dada dan punggung (Marsetyo et al. 2015). Pada awal proses pertumbuhan, proporsi tulang akan mengalami pertambahan lebih cepat dibandingkan dengan daging dan lemak dikarenakan tulang merupakan struktur utama dari tubuh. Pertumbuhan jaringan tubuh pada ternak dibedakan atas tiga tingkatan diantaranya adalah pertumbuhan tulang dan organ lain, pertumbuhan jaringan otot, dan pertambahan bobot karena penimbunan lemak (Rhido, 2011). 
Ayam Isa Brown diafkir pada umur 80 minggu karena semakin bertambahnya umur ayam maka telur yang dihasilkan akan mengalami penurunan kualitas, diakibatkan umur menurunkan kemampuan penceranaan dan metabolisme tubuh ayam sehingga kandungan mineral dalam tubuh ayam semakin berkurang. Menurut Sumadi (2017) untuk mengatasi kekurangan mineral pada ayam petelur umur 80 minggu keatas dapat diatasi dengan penambahan kalsium yang cukup ke dalam ransum. Ransum mempunyai peranan penting bagi ayam petelur yang digunakan untuk proses reproduksi dan proses produksi (Budiansyah 2010). Umumnya peternak ayam menggunakan ransum komersial untuk memenuhi kebutuhan pakan ternak ayamnya, karena ransum komersial telah disusun sedemikian rupa sehingga memenuhi standar kebutuhan zat makanan yang telah ditetapkan. Kandungan kalsium pada ransum komersial yaitu 3,13\% dan ayam petelur umur 20 minggu sampai afkir kandungan kalsium yang dibutuhkan adalah 3,25-4,25\% maka dari itu untuk memenuhi kebutuhan kalsium pada ayam petelur umur 100 minggu perlu penambahan mineral seperti kalsium. Widharto dan Marsudi (2017) menyatakan bahwa dengan penambahan kalsium dalam ransum belum dapat meningkatkan konsumsi pakan dan pertambahan bobot badan harian, tetapi dapat meningkatkan bobot karkas. Kekurangan pada ayam petelur afkir yaitu produksinya menurun, hand day production $61,14 \%$, kulit telur tipis dan ayam lumpuh, dalam hal ini untuk mengatasi masalah ini perlu ditambahkan mineral kalsium salah satu sumber mineral kalsium adalah dari kulit kerang. Kurniasih et al. (2017) menganalisis kandungan tepung kulit kerang dan memperoleh data sebagai berikut: kandungan kalsium $40 \%$, dan fosfor $1 \%$. Kalsium (Ca) merupakan bagian penting dari tulang dan gigi yang berperan sebagai kekuatan dari jaringan tubuh, kalsium mempunyai hubungan yang sangat kuat dengan jaringan tubuh pembentuk daging pada tubuh ayam.

Sehubungan dengan hal tersebut, penulis ingin mengetahui pengaruh pemberian tepung kulit kerang pada ransum komersial terhadap persentase karkas ayam Isa Brown umur 105 minggu

\section{MATERI DAN METODE}

\section{Materi}

\section{Tempat dan waktu penelitian}

Penelitian ini dilaksanakan di Desa Pesedahan, Kecamatan Manggis, Kabupaten Karangasem berlangsung selama empat minggu. 


\section{Ayam petelur}

Pada penelitian ini ayam petelur yang digunakan adalah ayam Isa Brown umur 100 minggu. Jumlah ayam petelur yang digunakan dalam penelitian ini sebanyak 60 ekor dengan bobot badan ayam rata-rata $1650 \mathrm{~g}$.

\section{Kandang dan perlengkapan}

Kandang yang digunakan adalah kandang baterai dengan ukuran panjang $30 \mathrm{~cm}$, lebar $20 \mathrm{~cm}$, tinggi $30 \mathrm{~cm}$ yang terbuat dari besi dan atap kandang menggunakan seng. Semua petak kandang sudah dilengkapi dengan tempat pakan dan tempat air minum

\section{Ransum dan air minum}

Ransum yang digunakan adalah ransum komersial KLS Super Plus untuk fase layer berumur 18-52 minggu yang diproduksi oleh PT. Wonokoyo Jaya Corporindo, dengan komposisi ransum disajikan dalam Tabel 1 , air minum yang diberikan bersumber dari PDAM.

\section{Tabel 1. Komposisi bahan penyusun ransum penelitian}

\begin{tabular}{lcccc}
\hline & \multicolumn{4}{c}{ Perlakuan $^{1}$} \\
\cline { 2 - 5 } Ransum & $\mathrm{A}^{2}$ & $\mathrm{~B}$ & $\mathrm{C}$ & $\mathrm{D}$ \\
\hline Ransum komersial & 100 & 99 & 98 & 97 \\
Tepung kulit kerang (\%) & 0 & 1 & 2 & 3 \\
Total & 0 & 100 & 100 & 100 \\
\hline
\end{tabular}

Keterangan :

1. Ransum Komersial produksi PT Wonokoyo.

2. A Ransum komersial tanpa tepung kulit kerang, B Ransum komersial dan $1 \%$ tepung kulit kerang, C Ransum komersial dan 2\% tepung kulit kerang, D Ransum komersial dan 3\% tepung kulit kerang.

Tabel 2. Kandungan nutrisi ransum penelitian

\begin{tabular}{lccccc}
\hline \multirow{2}{*}{ Kandungan Nutrien } & $\mathrm{A}^{2}$ & $\mathrm{~B}$ & $\mathrm{C}$ & $\mathrm{D}$ & Standar $^{3}$ \\
\cline { 2 - 6 } Energi Termetabolis Kkal/Kg & 2900 & 2871 & 2842 & 2813 & 2900 \\
Protein Kasar (\%) & 18 & 17,86 & 17,72 & 17,58 & $17-20$ \\
Lemak Kasar (\%) & 10,13 & 10,03 & 9,93 & 9,83 & $4-11$ \\
Serat Kasar (\%) & 3,08 & 3,05 & 3,02 & 2,99 & $3-8$ \\
Kalsium/Ca (\%) & 3,13 & 3,50 & 3,87 & 4,24 & $3,00-4,5$ \\
Posfor/P (\%) & 0,45 & 0,46 & 0,46 & 0,47 & $0,45-1,5$ \\
\hline
\end{tabular}

Keterangan :

1. A : Ransum komersial tanpa tepung kulit kerang.

B : Ransum komersial dan $1 \%$ tepung kulit kerang.

C : Ransum komersial dan $2 \%$ tepung kulit kerang.

D : Ransum komersial dan 3\% tepung kulit kerang.

2. Ransum Komersial produksi PT Wonokoyo.

3. Standar Scott et al. (1982) 


\section{Peralatan}

Alat-alat yang digunakan adalah terdiri dari kandang ternak, tempat ransum penelitian, tempat air minum, timbangan elektrik, berbagai wadah sampel, papan iris dan nampan plastik digunakan pada saat pemotongan serta alat tulis untuk mencatat setiap kegiatan yang dilaksanakan dari awal pemeliharaan sampai akhir pemotongan ternak.

\section{Metode}

\section{Rancangan penelitian}

Rancangan yang digunakan dalam penelitian ini adalah Rancangan Acak Lengkap (RAL) terdiri dari 4 perlakuan dan 5 ulangan. Setiap ulangan menggunakan 3 ekor ayam Isa Brown, sehingga total ayam yang digunakan adalah $4 \times 5 \times 3=60$ ekor ayam Isa Brown. Keempat Perlakuan tersebut adalah:

Perlakuan A : Ransum komersial tanpa tepung kulit kerang.

Perlakuan B : Ransum komersial dan $1 \%$ tepung kulit kerang.

Perlakuan C : Ransum komersial dan $2 \%$ tepung kulit kerang.

Perlakuan D : Ransum komersial dan 3\% tepung kulit kerang.

\section{Pengacakan ayam}

Prosedur pengacakan ayam dilakukan dalam penelitian ini yaitu ayam terlebih dahulu ditempatkan dalam kandang penelitian yang telah tersedia. Penempatan ayam dilakukan melalui teknik pengacakan lengkap dengan terlebih dahulu dilakukan penimbangan bobot badan dengan catatan bobot badan ayam homogen/koefisien variasi $<5 \%$. Setiap satu petak kandang baterai diisi satu ekor ayam, dimana secara keseluruhan terdapat 20 unit perlakuan.

\section{Pembuatan tepung kulit kerang}

Cangkang kerang dicuci bersih lalu di jemur dibawah sinar matahari hingga kering, cangkang kerang yang sudah kering dihancurkan hingga berukuran 2-3 $\mathrm{cm}$ dan diestraksi dengan $\mathrm{NaOH} 2 \mathrm{~N}$ dengan suhu $60^{\circ} \mathrm{C}$ selama 3 jam selanjutnya pencucian kembali dengan air mengalir hingga $\mathrm{pH}$ netral kemudian digiling dengan mesin dan terakhir yaitu pengayakan.

\section{Pencampuran bahan ransum}

Pencampuran ransum dilakukan dengan menimbang masing-masing bahan penyusun ransum sesuai dengan kebutuhan. Penimbangan dimulai dari bahan yang paling banyak, diikuti dengan bahan yang lebih sedikit. Bahan ransum yang sudah ditimbang diratakan di atas lembaran plastik dengan cara menempatkan bahan yang terbanyak dibagian paling bawah, selanjutnya bahan yang menengah hingga bahan paling sedikit, kemudian dibagi 
menjadi empat bagian. Masing-masing bagian diaduk rata, kemudian dicampur secara silang. Selanjutnya, campuran tersebut dijadikan satu dan diaduk sampai rata (homogen). Ransum yang sudah tercampur rata dimasukan ke dalam kantong plastik yang sudah diisi label sesuai perlakuan.

\section{Pemberian ransum dan air minum}

Pemberian ransum dan air minum diberikan ad libitum selama penelitian dan ransum diberikan 2 kali sehari yaitu pukul 07:00-08:00 WITA dan sore pukul 03:30-04:30 WITA. Pemberian ransum dilakukan dengan cara menaruh pakan pada tempat pakan yang sudah disiapkan di depan kandang battray setiap perlakuan. Air minum yang diberikan selama penelitian bersumber dari perusahaan air minum (PDAM).

\section{Pemotongan dan pengambilan karkas}

Ayam petelur sebelum dipotong terlebih dahulu ditimbang untuk mengetahui bobot hidup. Sebelum ayam dipotong ayam tidak diberi makan atau dipuasakan selama kurang lebih 12 jam, Setelah dipuasakan dilakukan pemotongan dengan pisau kecil dengan memotong Vena jugularis dan Arteri carotis di dasar leher, tanpa memutuskan trakhea. Setelah Vena jugularis dan Arteri carotis dipotong maka darah ditampung. Bila ayam telah mati, ayam dimasukan dalam air panas dengan suhu $65{ }^{0} \mathrm{C}$ selama 30 detik dilanjutkan dengan pencabutan bulu (Soeparno, 2009). Pengeluaran saluran pencernaan dan organ dalam dilakukan dengan membelah perut, pemotongan kaki dengan cara memotong pertautan $O s$ tarsal dengan Os tibia, pemotongan kepala dengan memotong sendi Atlanto occipitalis yaitu pertautan antara tulang sternum (vertebrae cevicalis) dengan tulang tengkorak bagian belakang (Os occipitalis). Pemisahan leher dari bagian punggung dilakukan pemotongan pada bagian tulang leher terakhir (Vertebrae cervicalis) dengan tulang punggung (Vertebrae thoracalis). Pemisahan karkas dikerjakan menurut USDA (1977). Untuk pemisahan bagian dada dari bagian punggung dengan memotong sepanjang pertautan antara tulang rusuk yang melekat pada punggung (Costae vertebralis) dengan tulang rusuk yang melekat pada dada (Costae sternalis) sampai sendi bahu, sehingga selain tulang rusuk dan tulang dada pada bagian dada akan ikut serta Os clavicula dan Os caracoid. Pemisahan bagian punggung dari paha dengan memotong sendi Articulation coxae antara Os femur (tulang paha) dengan $O s$ coxae. Bagian sayap dapat dipisahkan dengan memotong persendian antara Os humerus dengan Os scapula.

\section{Variabel yang diamati}

Variabel yang diamati dalam penelitian ini yakni: 
1. Bobot potong (g): Bobot potong diperoleh dengan cara menimbang ayam Isa Brown yang telah dipuasakan selama 12 jam sebelum di potong.

2. Bobot karkas (g): Bobot ayam setelah dipotong yang telah dikurangi yaitu darah, bulu, kepala, leher, kaki, dan organ dalam.

3. Persentase karkas (\%): Nilai persentase karkas diperoleh dengan membandingkan bobot karkas dengan bobot sebelum ayam Isa Brown dipotong dikali 100\%.

$$
\text { Persentase karkas (\%): } \frac{\text { Bobot karkas (g) }}{\text { Bobot hidup (g) }} \times 100 \%
$$

4. Persentase dada (\%): Nilai persentase dada diperoleh dengan cara membandingkan bobot dada dengan bobot karkas dikalikan $100 \%$.

5. Persentase sayap (\%): Nilai persentase sayap diperoleh dengan cara membandingkan bobot sayap dengan bobot karkas dikalikan $100 \%$.

6. Persentase paha (\%): Nilai persentase paha diperoleh dengan cara membandingkan bobot paha dengan bobot karkas dikalikan $100 \%$.

7. Persentase punggung (\%): Nilai persentase punggung diperoleh dengan cara membandingkan bobot punggung dengan bobot karkas dikalikan 100\%

\section{Analisis statistik}

Data yang dihasilkan dianalisis dengan sidik ragam (Anova) dan apabila terdapat nilai berbeda nyata $(\mathrm{P}<0,05)$ maka dilanjutkan dengan uji Duncan (Steel dan Torrie, 1989).

\section{HASIL DAN PEMBAHASAN}

Tabel 3. Pengaruh pemberian tepung kulit kerang pada ransum komersial terhadap persentase karkas ayam Isa Brown umur 105 minggu.

\begin{tabular}{llllll}
\hline \multirow{2}{*}{ Variabel } & \multicolumn{5}{c}{ Perlakuan $^{1}$} \\
\cline { 2 - 5 } & \multicolumn{1}{c}{$\mathrm{A}$} & \multicolumn{1}{c}{$\mathrm{B}$} & $\mathrm{C}$ & $\mathrm{D}$ & SEM $^{2}$ \\
\hline Bobot Potong (g) & $1670,80^{\mathrm{a}}$ & $1683,40^{\mathrm{a}}$ & $1680,00^{\mathrm{a}}$ & $1657,20^{\mathrm{a} 3}$ & 0,6 \\
Bobot Karkas (g) & $955,80^{\mathrm{a}}$ & $973,60^{\mathrm{a}}$ & $966,20^{\mathrm{a}}$ & $967,00^{\mathrm{a}}$ & 13,25 \\
Persentase Karkas (\%) & $57,22^{\mathrm{a}}$ & $57,85^{\mathrm{a}}$ & $57,53^{\mathrm{a}}$ & $58,34^{\mathrm{a}}$ & 0,63 \\
Persentase Dada (\%) & $35,50^{\mathrm{a}}$ & $35,52^{\mathrm{a}}$ & $35,50^{\mathrm{a}}$ & $35,05^{\mathrm{a}}$ & 0,56 \\
Persentase Sayap (\%) & $11,42^{\mathrm{a}}$ & $10,35^{\mathrm{a}}$ & $12,01^{\mathrm{a}}$ & $10,87^{\mathrm{a}}$ & 0,69 \\
Persentase Paha (\%) & $25,79^{\mathrm{a}}$ & $27,55^{\mathrm{b}}$ & $25,73^{\mathrm{a}}$ & $26,93^{\mathrm{b}}$ & 0,20 \\
Persentase Punggung (\%) & $27,33^{\mathrm{a}}$ & $26,58^{\mathrm{a}}$ & $26,76^{\mathrm{a}}$ & $27,16^{\mathrm{a}}$ & 0,57 \\
\hline
\end{tabular}

Keterangan :

1. A : Ransum komersial tanpa tepung kulit kerang.

B : Ransum komersial dan $1 \%$ tepung kulit kerang.

C : Ransum komersial dan $2 \%$ tepung kulit kerang.

D : Ransum komersial dan 3\% tepung kulit kerang. 
2. Standart error of the treatment means

3. Nilai dengan huruf yang berbeda pada baris yang sama adalah berbeda nyata $(\mathrm{P}<0,05)$

Hasil penelitian bobot potong ayam petelur Isa Brown pada perlakuan A, B, C dan D dengan pemberian tepung kulit kerang pada ransum komersial secara statistik menunjukkan tidak berbeda nyata $(\mathrm{P}>0,05)$ (Tabel 3) dibandingkan dengan kontrol. Hal ini disebabkan karena ransum komersial ditambahkan tepung kulit kerang yang diserap tubuh ternak tidak berbeda sehingga menyebabkan pertumbuhan ayam hampir sama. Penelitian ini sesuai dengan pernyataan Suprijatna et al. (2005) menyatakan apabila kebutuhan energi telah terpenuhi maka ayam akan mengurangi, bahkan menghentikan konsumsi ransum, oleh karena itu tingkat kandungan zat-zat makanan dalam ransum harus memadai atau menyesuaikan dengan tingkat kandungan energi ransum. Pernyataan diatas diperkuat dengan pendapat Nitis (1980) bahwa ransum yang tidak seimbang antara energi dan protein akan mengganggu atau menghambat pertumbuhan ayam. Hal ini diduga terkait dengan kadar kalsium dan fosfor dalam pakan dengan semakin tingginya ekskresi kalsium dalam feses yang mempengaruhi proses metabolisme dalam tubuh dan selebihnya akan diekskresikan melalui feses. Tinggi kalsium dalam tubuh akan menurunkan sekresi hormon paratiroid dan meningkatkan hormon kalsitonin serta menekan penggunaan protein, lemak, vitamin, mineral $\mathrm{P}, \mathrm{Mg}, \mathrm{Fe}, \mathrm{I}, \mathrm{Zn}$, dan Mn (Linder, 1992)

Bobot karkas dengan pemberian tepung kulit kerang pada ransum komersial untuk perlakuan A, B, C dan D secara statistik menunjukkan tidak berbeda nyata $(\mathrm{P}>0,05)$ (Tabel 3) dibandingkan dengan kontrol. Hal ini dipengaruhi oleh bobot hidup, karena bobot hidup yang besar akan diikuti oleh bobot karkas yang besar pula, dan sebaliknya. Hal ini sesuai dengan pendapat Haroen (2003) menyatakan bahwa berat karkas pada ayam dipengaruhi oleh bobot potong sehingga semakin tinggi bobot potong maka bobot karkas yang dihasilkan juga semakin tinggi, selain itu faktor genetik dan lingkungan dapat mempengaruhi laju pertumbuhan dan komposisi tubuh yang meliputi distribusi berat dan komponen karkas. Pernyataan diatas diperkuat dengan pendapat Resnawati (2004) bobot karkas yang di hasilkan dipengaruhi oleh beberapa faktor yaitu umur, jenis kelamin, bobot hidup, kualitas ransum serta strain yang dipelihara. Disamping itu berat karkas juga dipengaruhi oleh organ-organ tertentu yang tidak termasuk karkas seperti kepala, kaki, bulu dan organ dalam, dimana semakin berat organ - organ tersebut pada umur pemotongan yang sama, maka berat karkas semakin rendah (Cakra, 1986). Kadar kalsium melebihi 2\% dapat menurunkan pengunaan pakan dan menurunkan pertumbuhan ayam pedaging (Piliang, 2000). 
Persentase karkas ayam petelur Isa Brown pada perlakuan A, B, C dan D dengan pemberian tepung kulit kerang pada ransum komersial secara statistik menunjukkan tidak berbeda nyata $(\mathrm{P}>0,05)$ (Tabel 3) dibandingkan dengan kontrol. Bobot karkas yang tinggi akan menghasikan persentase karkas yang tinggi pula atau sebaliknya. Hal ini sejalan dengan pernyataan Dewanti et al. (2013) menyatakan bahwa persentase karkas dipengaruhi oleh bobot potong, semakin tinggi bobot potong dan bobot karkas maka akan berpengaruh terhadap persentase karkas yang semakin tinggi, sedangkan persentase karkas yang lebih rendah dipengaruhi oleh bobot potong yang lebih rendah pula. Pernyataan diatas sesuai dengan pendapat Suhendra et al. (2015) persentase karkas erat hubungannya dengan berat karkas dan berat potong. Bangun et al. (2013) bahwa kadar kalsium yang sama akan menghasilkan pertumbuhan tulang dan daging yang tidak berbeda.

Persentase dada ayam petelur Isa Brown pada perlakuan A, B, C dan D dengan pemberian tepung kulit kerang pada ransum komersial secara statistik menunjukkan tidak berbeda nyata $(\mathrm{P}>0,05)$ (Tabel 3) dibandingkan dengan kontrol. Potongan bagian dada unggas adalah tempat perdagingan yang tebal dengan persentase tulang yang kecil sehingga pada umur yang lebih muda perdagingan bagian dada masih sedikit dan akan meningkat seiring dengan umur yang meningkat. Hal ini disebabkan karena potongan karkas komersial bagian dada merupakan bagian karkas yang banyak mengandung otot jaringan yang perkembangannya dipengaruhi oleh zat makanan khususnya protein. Pernyataan diatas sesuai dengan pendapat Pribady (2008) bahwa pertumbuhan potongan dada tumbuh lebih lambat dibandingkan dengan pertumbuhan secara umum. Erisir et al. (2009), bahwa semakin tua umur potong ayam menghasilkan berat pada bagian dada yang semakin tinggi.

Hasil penelitian persentase sayap ayam petelur Isa Brown pada perlakuan A, B, C dan D dengan pemberian tepung kulit kerang pada ransum komersial secara statistik menunjukkan tidak berbeda nyata $(\mathrm{P}>0,05)$ (Tabel 3) dibandingkan dengan kontrol. Hal ini disebabkan karena pada bagian sayap ayam Isa Brown didominasi oleh tulang, sedangkan untuk produksi daging yang dihasilkan sangat sedikit sehingga dengan meningkatnya umur ayam maka persentasenya akan menurun. Penelitian ini sejalan dengan pernyataan Soeparno (2009) menyatakan bahwa bagian-bagian tubuh yang paling banyak tulang adalah sayap, kepala, leher dan kaki, sehingga persentasenya semakin menurun dengan meningkatnya umur ayam, karena bagian-bagian ini mempunyai pertumbuhan yang konstan pada ayam dewasa. Ariawan et al. (2016) bagian sayap didominasi oleh komponen tulang dan kurang berpotensi untuk menghasilkan daging. Pernyataan diatas diperkuat dengan pendapat Dewi (2010) produksi 
daging tulang dari ayam kampung umur 2-10 minggu tumbuh dengan kecepatan yang berbeda sesuai dengan meningkatnya umur. Menurut Nita et al. (2015) bahwa zat-zat makanan berupa protein dan energi serta mineral digunakan untuk pembentukan tulang, daging dan bulu yang didasarkan pada ukuran dan struktur sayap.

Hasil penelitian persentase paha ayam petelur Isa Brown pada perlakuan B dan D dengan pemberian tepung kulit kerang pada ransum komersial secara statistik menunjukkan berbeda nyata $(\mathrm{P}<0,05)$ lebih tinggi dibandingkan dengan kontrol. Persentase paha ayam yang mendapat perlakuan $\mathrm{C}$ lebih rendah tidak berbeda nyata $(\mathrm{P}>0,05)$ dibandingkan kontrol. Hal ini disebabkan karena kandungan kalsium dan fosfor pada ransum komersial ditambahkan tepung kulit kerang berperan penting dalam pertumbuhan tulang, pertumbuhan tulang yang baik akan berpengaruh pada pertumbuhan daging yang terdapat pada ternak tersebut. Penelitian ini sejalan dengan pernyataan Maghfiroh et al. (2014) kalsium dan fosfor memiliki sifat yang dinamis, dapat dibentuk dan diserap kembali sehingga $\mathrm{Ca}$ dan $\mathrm{P}$ memiliki peran yang penting untuk pembentukan tulang. Selanjutnya diperkuat dengan pernyataan Siahaan et $a l$. (2012) kalsium di dalam ransum yang dikonsumsi, diserap oleh usus halus ke dalam darah dengan membentuk ion bebas, berikatan dengan protein dan ion tak larut selanjutnya ditransportasikan untuk pembentukan tulang dan daging.

Persentase punggung ayam petelur Isa Brown pada perlakuan A, B, C dan D dengan pemberian tepung kulit kerang pada ransum komersial secara statistik menunjukkan tidak berbeda nyata $(\mathrm{P}>0,05)$ (Tabel 3) dibandingkan dengan kontrol. Hal ini disebabkan karena punggung adalah bagian yang didominasi oleh tulang dan kurang berpotensi untuk menghasilkan daging. Hasil penelitian ini sesuai dengan Ilham (2012) yang menyatakan bahwa pada bagian punggung bukan merupakan bagian tempat terjadinya deposisi daging yang utama sehingga pada masa pertumbuhan, nutrien untuk pembentuk daging terdapat pada tempat-tempat deposisi daging. Selain itu bagian punggung pada ayam tidak hanya disusun oleh otot-otot jaringan namun juga disusun oleh kerangka tulang dan sel-sel penyusun punggung merupakan sel yang stabil (Nugraha et al. 2018). Hal ini diperkuat dengan pernyataan Soeparno (2009) menyatakan bahwa ada hubungan yang erat antara berat karkas dan bagian potongan komersial karkas dengan bobot potong, sehingga apabila dari hasil analisis bobot potong dan karkas didapat hasil yang tidak berpengaruh nyata maka hasilnya tidak jauh berbeda pada bagian-bagian karkasnya. 


\section{SIMPULAN DAN SARAN}

\section{Simpulan}

Dari hasil penelitian ini dapat disimpulkan bahwa dengan pemberian tepung kulit kerang pada level 1\% dan 3\% pada ransum komersial dapat meningkatkan persentase paha, namun tidak dapat meningkatkan bagian bobot potong, bobot karkas, persentase karkas, persentase dada, persentase sayap dan persentase punggung ayam Isa Brown umur 105 minggu.

\section{Saran}

Dari hasil penelitian ini, disarankan kepada peternak untuk meningkatkan bobot paha pada ayam petelur Isa Brown dapat dilakukan dengan penambahan tepung kulit kerang $1 \%$ dan 3\% pada ransum komersial karena secara nyata dapat meningkatkan persentase paha.

\section{UCAPAN TERIMAKASIH}

Penulis mengucapkan terimakasih yang sebesar - besarnya kepada Rektor Universitas Udayana Prof. Dr. dr. A. A. Raka Sudewi, Sp. S (K), Dekan Fakultas Peternakan Dr. Ir. I Nyoman Tirta Ariana, MS. dan seluruh responden yang telah bekerja sama dengan baik dalam pengumpulan data selama penelitian ini. Terimakasih yang mendalam juga penulis sampaikan kepada pihak - pihak yang membantu menyelesaikan penelitian ini.

\section{DAFTAR PUSTAKA}

Ariawan. P. T. B., N. W. Siti, dan N. M. S. Sukmawati. 2016. Pengaruh pemberian ransum diferentasi dengan probiotik berbasis sari daun pepaya terhadap potongan karkas komersial ayam kampung. J. Peternakan Tropika. 2 (4): $351-365$.

Bangun, G. D. D., L. D. Mahfudz dan D. Sunarti. 2013. Pengaruh penggunaan tepung rumput laut (Gracilaria verrucosa) dalam ransum ayam broiler terhadap berat ukuran tulang tibia dan tarsometatarsus. J. Anim Agric. 2 (1) : $489-496$.

Budiansyah, B. 2010. Performan ayam broiler yang diberi ransum yang mengandung bungkil kelapa yang difermentasi ragi tape sebagai pengganti sebagian ransum komersial. J. ilmiah ilmu-ilmu peternakan 9(5):8-13.

Cakra, I. G. L. O., 1986. Pengaruh Pemberian Hijauan Versus Top Mix Terhadap Berat Karkas dan Bagian - Bagiannya pada Ayam Pedaging Umur 0 - 8 minggu. Skripsi Sarjana Peternakan Fakultas Peternakan Universitas Udayana.

Dewanti, R., M. Irham, dan Sudiyono. 2013. Pengaruh penggunaan enceng gondok (Eichornia crassipes) terfermentasi dalam ransum terhadap persentase karkas, non karkas, dan lemak abdominal itik lokal jantan umur delapan minggu. Buletin Peternakan. 37(1): $19-25$. 
Dewi, G. A. M. K. 2010. Pengaruh penggunaan level energi - protein ransum terhadap produksi karkas ayam kampung. Prosiding Seminar Nasional Tentang Unggas Lokal ke IV. Hal; 222-228

Erisir Z, O. Poyraz, E. Onbasilar, E. Erdem, G. Oksuztepe. 2009. Effect of housing system, swimming pool and slauger age on duck performance, carcass and meat characteristics. J Anim Vet Adv 8 (9): 1864-1869.

Hargitai, R., R. Mateo, Andj. Torok. 2011. Shell tickness and pore density in relation to shell colouration female characterstic, and enviroental factors in the collared flycatcher ficedulaalbicollis. J. Ornithol. 152: 579-588.

Haroen, U. 2003. Respon ayam broiler yang diberi tepung daun sengon (albizzia falcataria) dalam ransum terhadap pertumbuhan dan hasil karkas. J. Ilmiah Ilmu-ilmu Peternakan. 6 (1): 34-41.

Ilham, M. 2012. Pengaruh Penggunaan Eceng Gondok (Eichornia crassipes) Fermentasi dalam Ransum Terhadap Persentase Karkas, Nonkarkas, dan Lemak Abdominal Itik Jantan Umur Delapan Minggu. Skripsi. Fakultas Pertanian. Universitas Sebelas Maret. Surakarta

Isa Brown Commercial Layers. 2009. General Management Guide Commercial Isa Brown. Pondoras.

Judge, M. D., E. D. Aberle, J. C. Forrest, H. B. Hedrick dan R. A. Merkel. 1989. Principles of Meat Science. Kendall Hunt Publishing Company. Dubuque. Iowa.

Kurniasih, D., Rahmat, B. M., Handoko, C. R dan A. A. Zuhri. 2017. Pembuatan Pakan Ternak dari Limbah Cangkang Kerang. Politeknik Perkapalan Negeri Surabaya. Surabaya.

Linder, M. C. 1992. Biokimia Nutrisi dan Metabolisme. Terjemahan: A. Parakkasi. Penerbit Universitas Indonesia, Jakarta.

Maghfiroh, K., B. Sukamto dan L. D. Mahfudz. 2014. Penggunaan sorgum atau kulit pisang terhidrolisis terhadap retensi kalsium dan massa kalsium tulang pada ayam broiler. Agromedia. 32 (1) : $54-62$.

Marsetyo, N. Marfuah dan Hafsah. 2015. Pengaruh level penggunaan daun katuk (Saoropus androgynous) pada ransum terhadap penampilan produksi dan persentase karkas ayam kampung. J. Nature. 4 (1):73-83

Nita, N. S. E. Dihansih dan Anggraeni. 2015. Pengaruh pemberian kadar protein pakan yang berbeda terhadap bobot komponen karkas dan nonkarkas ayam jantan petelur. J. Peternakan Nusantara 1(2):2442-2541.

Nitis, I. M. 1980. Makanan Ternak salah satu sarana Untuk Meningkatkan Produksi ternak. Pidato Pengukuhan Guru Besar dalam Ilmu Makanan ternak. FKHP Universitas Udayana. Denpasar

Nugraha, G. A., I. M. Nuriyasa, dan A. W. Puger. 2018. Karkas ayam kampung umur 11 minggu yang diberi ransum dengan tingkat protein yang berbeda. J. Peternakan Tropika. 1 (6): 118-128. 
Piliang, W. G .2000. Nutrisi Mineral. Edisi III. PAU Ilmu Hayati, Institut Pertanian Bogor, Bogor.

Pribady, W. A. 2008. Produksi Karkas Angsa (Anser cygnoides) pada Berbagai Umur Pemotongan. Skripsi. Bogor (ID): Institut Pertanian Bogor. Bogor.

Resnawati, H. 2004. Bobot potongan karkas dan lemak abdomen ayam ras pedaging yang diberi ransum mengandung tepung cacing tanah (Lumbricus rubellus). Seminar Nasional Teknologi Peternakan dan Veteriner. Balai Penelitian Ternak. Bogor.

Rhido, M., 2011. Pertumbuhan dan Perkembangan Ternak. Kanisius, Yogyakarta.

Samadi and F. Liebert. 2006. Estimation of nitrogen maintenance requirements and potential for nitrogen deposition in fast-growing chickens depending on ege and sex. Poult.Sci.85:1421-1429.

Scott, M. L., M. C. Nesheim dan R. J. Young. 1982. Nutrition of Chicken $3^{\text {rd }}$ Ed. Scottan Association Inc. West Port, Connecticut.

Siahaan, N. B., D. Sunarti dan V. D. Yunianto. 2012. Pengaruh penggunaan kulit pisang biokonversi dalam ransum terhadap penyerapan kalsium serta kekuatan tulang ayam broiler. J. Ilmu - Ilmu Peternakan. 24 (3) : 18 - 23.

Soeparno, 2009. Ilmu dan Teknologi Daging. Cetakan V. Gajah Mada University Press. Yogyakarta.

Steel, R. G. D dan J. H Torrie. 1989. Prinsip dan Prosedur Statistika. PT. Gramedia. Pustaka Utama, Jakarta.

Suhendra, I P. N. D., G. A. M. Kristina Dewi, dan N W. Siti. 2015. Pengaruh biosuplemen isi rumen sapi bali pada ransum terhadap berat dan komposisi fisik karkas itik bali jantan. J. Peternakan Tropika. 2 (3): 366 - 385

Sumadi, K. 2017. Kebutuhan Mineral Pada Ayam Petelur. Ilmu Gizi Ternak Unggas. Fakultas Peternakan. Universitas Udayana.

Suprijatna, E., U. Atmomarsono dan R. Kartasudjana. 2005. Ilmu Dasar Ternak Unggas. Penebar Swadaya, Jakarta.

USDA (United States Departement of Agriculture). 1977. Poultry Grading Manual. U. S Government Printing Office. Washington. D. C.

Widharto dan W. Marsudi 2017. Pengaruh penambahan tepung tulang (cuttelfish bone) dalam ransum terhadap konsumsi pakan, pertambahan bobot badan, dan bobot karkas. J. ilmu-ilmu pertanian.1 (2):132-139. 